\title{
TÉNYFELTÁRÓ SZAKMAI JELENTÉS 2020.1.
}

\author{
KÖZREADJA: \\ SZOCIÁLIS SZAKMAI TÉNYFELTÁRÓ \\ MUNKACSOPORT
}

A jelentést egy független szakemberekből álló munkacsoport készítette.

A jelentés, vagy annak egy része kizárólag a munkacsoport engedélyével publikálható.

2020. január 


\section{TARTALOMJEGYZÉK}

BEVEZETÉS

IDÖKÖZI TÉNYFELTÁRÓ JELENTÉS K. M. ÜGYÉBEN (2019. szeptember 29.)

0. ELőszó

1. A VIZSGÁlat MóDSZERE

1.1. LÉTREJÖTT SZEMÉLYES KONZULTÁCIÓK

1.2. JELENTÉS_TERVEZET ÉSZREVÉTELEZÉSE

2. A JELENTÉS MEGÁLLAPÍTÁSAI - REKONSTRUKCIÓ

2.1. KORÁBBI ELŐZMÉNYEK

2.2. KÖZVETLEN ELŐZMÉNY _

ÁLLAPOTVÁLTOZÁS HÁTRALÉKBAN MARADÁSSAL

2.2.1. FIZETENDŐ DÍJAK — TARTOZÁS

2.3. ELSŐ SZAKASZ -

BÉRLŐBŐL HAJLÉKTALANNÁ VÁLÁS

2.3.1. PANASZRA OKOT ADÓ RENDETLENSÉG_KOSZ_BǓZZ KIALAKULÁSA A LAKÁSBAN

2.4. MÁSODIK SZAKASZ _

AZ ELSŐ LAKÁSNÉLKÜLI NAPOK

2.5. HARMADIK SZAKASZ _

KOMMUNIKÁCIÓ A MÉDIÁN KERESZTÜL, MERRE VAN AZ ELŐRE?

2.6. NEGYEDIK SZAKASZ

VISSZA AZ ÖNKORMÁNYZATHOZ

3. A MUNKACSOPORT MEGÁlLAPÍTÁSAI

3.1. SZOCIÁLIS SEGÍTÉS_ ÉRDEKVÉDELEM

3.2. SZERVEZETI SZINTÜ TANULSÁGOK

3.3. ESETKEZELÉS _ ESETVITEL TANULSÁGAI

4. KIEGÉSZÍTÉS AZ IDŐKÖZI TÉNYFELTÁRÓ JELENTÉSHEZ

\section{MELLÉKLET}




\section{BEVEZETÉS}

2019 végén néhányan - közelebbröl: Aczél Ágnes, Darvas Ágnes, Györi Péter, Kozma Judit és Tánczos Éva - úgy döntöttünk, hogy útjára indítunk egy Szociális Szakmai Tényfeltáró Munkacsoport elnevezésü független, önkéntes, szakértői szervezödést a szociális szakma fejlesztése érdekében. A munkacsoport elsösorban olyan helyzetekben, esetekben folytatna tényfeltáró munkát, amikor egy-egy érdekvédö, jogvédö szervezet a saját tevékenysége során, a saját szempontjai alapján már elegendö mennyiségü információt és az érintettek legalább egy részének a hozzájárulását összegyüjtötte ahhoz, hogy lefolytatható legyen a szociális szakmai szempontú más szempontoktól mentes - tényfeltáró vizsgálat. Egy-egy ilyen vizsgálat eredményeit anonimizált Jelentésben kívánjuk közreadni. E jelentések közvetlen célja az adott helyzet, eset körülményeinek, a szereplök lépéseinek tárgyszerü rögzítése, ezen keresztül a szociális szférában dolgozók pontos tájékoztatása, illetve a szakmai tanulságok levonásának a lehetövé tétele. Úgy gondoljuk, hogy ezzel, a magunk eszközeivel hozzájárulhatunk az e területen dolgozók szakmai munkájának a megerösitéséhez.

Első, egy szakmai szervezet felkérésére készitett, és itt most közreadott jelentésünk két részböl áll: elöször ismertetjük azt az Időközi tényfeltáró jelentést, melynek elkészitésén 2019. augusztusában és szeptemberében dolgoztunk (K. M. ügyében), majd röviden összefoglaljuk ennek az idöközi jelentésnek az utóéletét Kiegészítés az időközi tényfeltáró jelentéshez címmel.

IDÖKÖZI TÉNYFELTÁRÓ JELENTÉS K.M. ÜGYÉBEN

(2019. szeptember 29.)

\section{ELŐSZÓ}

K.M. - 80 éves nyugdíjas - jelenleg, augusztus óta ideiglenesen egy hajléktalanok (idősek) otthonának a lakója, ahol megfelelő ellátásban részesül, és arra vár, hogy a lakóhelye szerinti önkormányzat visszaengedje bérlakásába. Lakásának kulcsait július végén adta vissza (birtokba), miután korábban bérleti szerződését kettő havi lakbértartozás miatt fölmondták, majd többször fölszólították a lakás elhagyására. Az eset rögtön igen nagy sajtónyilvánosságot kapott, a sajtóban megjelent információk, dezinformációk és vélemények a szociális szakmán belül is és a szociális szakma körül is nagy hullámokat vertek.

Ezért egy szakmai szervezet ad hoc tényfeltáró csoportot kért fel a történtek sok szempontból történő megismerésére és leírására.

Hangsúlyozzuk, hogy ennek a tényfeltáró munkának, az elkészült Jelentésnek nem célja értékelni, értékítéletet vagy éppen etikai ítéletet megfogalmazni. A vizsgált ügy számos egyedi, de számos általános szakmai tanulság levonására is alkalmas, több aktuális szakmai kérdés közös megvitatását, átgondolását teszi lehetővé.

A munkacsoport vizsgálódása eredményeit e Jelentésben rögzíti. A munkát elindító szervezet az elkészült Jelentés szakmai nyilvánosságának és megvitatásának biztosítására nem látott és nem talált megfelelő lehetőséget, így azt most az ad hoc munkacsoport tagjai hozzák nyilvánosságra.

Az Ad Hoc munkacsoport tagjai:

Aczél Ágnes, Darvas Ágnes, Győri Péter, Kozma Judit, Tánczos Éva. 


\section{A VIZSGálat MÓdSZERE}

A vizsgálatot 2019 augusztusában és szeptemberében végeztük. A vizsgált időszak kezdete 2019. január közepe, K.M. bérleti szerződése felmondásának a napja, illetve az e felmondást megelőző hat hónap. A vizsgált időszak vége: 2019. szeptember közepe. Az ad hoc munkacsoport tényfeltáró vizsgálatának lezárásakor azonban K.M. helyzete még nem rendeződött, ügye még folyik, ezért jelentésünk jelenleg csak Időközi jelentésnek tekinthető.

A vizsgálat módszere: az érintetten túl megkerestük K. M. szomszédjait, az ügyben közremüködő család- és gyermekjóléti központot (csgyk), szociális szolgálatot, diszpécserszolgálatot, a K. M.-et ellátó alapítványt, valamint az ügyben érintett érdekvédő szerveződést. Részben személyes találkozót kértünk, hogy szóban meghallgathassunk mindenkit, aki az ügyben közvetlenül érintett lehet, abban közremüködött, részben kértük az üggyel közvetlenül összefüggő (anonimizált) dokumentumok megtekintését.

Mindezt a titoktartás és diszkréció szigorú betartása mellett. Minden vizsgálatban együttmüködő számára lehetővé tettük, hogy a Jelentés-tervezetet megismerhesse, és ahhoz észrevételeket tehessen.

K. M.-től hozzájárulást kértünk a reá vonatkozó információk felhasználásához.

Ezt követően a Jelentést a munkacsoport tagjai közösen véglegesítették, majd átadták a felkérő szervezet vezetőjének.

A Jelentés számos, a tényfeltárás során tudomásunkra jutott információt nem tartalmaz - a fenti eljárás szabályainak betartása miatt. Különösen sajnáljuk, hogy a helyi csgyk közvetlenül K. M.mel foglalkozó munkatársa - felettesei határozott utasítására - nem müködött együtt az ad hoc munkacsoporttal.

Az ügyben történteket - a minél jobb nyomon követhetőség érdekében - kronológikus sorrendben - de az ügy anonimitásának érdekében a rendelkezésünkre álló pontos dátumok nélkül - mutatjuk be. Ugyanakkor fontos megjegyezni, hogy a közremüködő szakemberek, szervezetek sokszor nem rendelkeztek naprakész információkkal az előzményekröl, munkacsoportunknak utólag, számos dokumentum alapján kellett rekonstruálnia, mikor mi történt.

A tények rekonstrukcióját követően pontokba szedve röviden összefoglaljuk a tényfeltáró munkacsoport - hangsúlyozottan szakmai - megállapításait, mind a szociális segítés és az érdekvédelem vonatkozásában, mind a szervezeti szintű tanulságokat, illetve a konkrét esetkezelés/esetvitel tanulságait.

Az ügyben számos hivatalos vizsgálat is indult, ezek részben még folynak, illetve eredményeik még nem ismertek. 


\section{LÉTREJÖTT SZEMÉLYES KONZULTÁCIÓK}

- $\quad$ K. M. - többszöri leülésben

- $\quad$ K. M. ügyével foglalkozó csgyk munkatárs - telefonos kapcsolat és email-levelezés, az együttmüködéstől ,főnökei utasítására” elzárkózott

- $\quad$ csgyk vezetője és szociális szolgálat vezetője többszöri megkeresést követően, kizárólag a szociális osztály vezetőjének a jelenlétében, hármasban együtt, csoportos konzultációs formában álltak a munkacsoport rendelkezésére

- diszpécserszolgálat vezetője

- $\quad$ K. M. jelenlegi (hajléktalanok otthona) segítője, gondozója

- K. M. ügyével foglalkozó szakemberek az érdekvédő szerveződés részéről

\subsection{JELENTÉS_TERVEZET ÉSZREVÉTELEZÉSE}

A jelentés-tervezetet észrevételezésre megküldtük 2019 szeptemberében megküldtük az az érintetteknek és közreműködőknek. Észrevételt tett:

$\bullet \mathrm{K} . \mathrm{M}$.

- csgyk munkatárs

megküldve jóváhagyta

- csgyk vezetöje megküldve írásban nem válaszolt

kihúzva,

• szociális szolgálat vezetője

- szociális osztály vezetője

- diszpécserszolgálat vezetője

- K. M. jelenlegi gondozója

• érdekvédő szerveződés szakemberei megküldve kérésükre saját közléseik

megküldve saját közléseik megküldve kihúzva megküldve észrevételt átvezettük megküldve jóváhagyta megküldve észrevételek egy részét átvezettük

\section{A JELENTÉS MEGÁLLAPÍTÁSAI - REKONSTRUKCIÓ}

\subsection{KORÁBBI ELÖZMÉNYEK}

K. M. (80) 2013 óta lakik a szóban forgó kis alapterületü, komfortos, villanyradiátorral fütött önkormányzati bérlakásban, határozatlan idejü bérleti szerződés alapján. Ezt megelőzően a volt házastársával (már korábban elváltak) és anyósával együtt bérlőtársként béreltek egy nagy alapterületü önkormányzati bérlakást (ott velük lakott volt házastársa felnőtt fia is). Miután a cég, ahol dolgozott, megszünt, kényszerüen nyugdíjazták, egészsége megroppant, 2011-ben K. M. felkereste a vagyongazdálkodásért felelős szervezet azzal, hogy a nagy alapterületü lakás megemelkedett költségelvü lakbére és rezsije már túl nagy teher számukra, el tudnák-e cserélni két kisebbre. Végül az a megoldás született, hogy anyósa térítés ellenében lemondott bérlőtársi jogviszonyáról, volt házastársa és fia egy 40 négyzetméter körüli bérlakást kapott, ő pedig egy alig 20 nm-es, egyszobás, föző fülkével, zuhany-WC-vel rendelkező komfortos lakásba költözött. Munkahelye megszünését, kényszerü nyugdíjazását, egészségének megroppanását, majd a nagylakás elvesztését - elmondása szerint -máig nem heverte ki.

K. M.-nek négy felnőtt gyereke van, velük a kapcsolatot nem tartja.

Nyugdíjazása előtt egy nagyvállalatnál dolgozott középvezetőként, jelenlegi nyugdíja 110.000 Ft, ezen letiltás nincs.

A beköltözést követően, még 2013-2014-ben volt mintegy 29 ezer forintos dijhátraléka, ezt annak idején kiegyenlítette. 2014-ben kérelemmel fordult az önkormányzathoz, hogy költségalapú lakbérét szociális lakbérre módosítsák. Ezt a kérelmét elutasították. Továbbra is költségalapú lakbért fizetett. 
2018 őszét megelőzően folyamatosan fizette a lakbért (plusz közös költség) és az egyéb díjakat.

K. M. az elmúlt évek során igen rendszeres életmódot folytatott, mindennap délelőtt elsétált a közelben lévő boltokba, illetve az azokhoz közel lévő étkezdében elfogyasztotta ebédjét, majd kisebb sétát követően hazament.

\subsection{KÖZVETLEN ELÖZMÉNY _ ÁLLAPOTVÁLTOZÁS HÁTRALÉKBAN MARADÁSSAL}

\subsubsection{FIZETENDŐ DÍJAK _ TARTOZÁS}

Mivel az ügyben a Felmondás alapjául a lakbértartozás szolgált, ezért ennek körülményeit röviden össze kell foglalnunk:

\begin{tabular}{|l|c|c|c|}
\hline $\begin{array}{c}\text { A 21 nm-es } \\
\text { önkormányzati } \\
\text { bérlakás }\end{array}$ & $\begin{array}{c}\text { Havi lakbére } \\
\text { (majd használati } \\
\text { díja) }\end{array}$ & $\begin{array}{c}\text { A lakbéren túl } \\
\text { fizetendő } \\
\text { közös költség }\end{array}$ & Együtt \\
\hline 2018. júliusig & $14.807 \mathrm{Ft}$ & $1.295 \mathrm{Ft}$ & $16.102 \mathrm{Ft}$ \\
\hline 2018. augusztustól & $14.807 \mathrm{Ft}$ & $3.146 \mathrm{Ft}$ & $17.953 \mathrm{Ft}$ \\
\hline 2019. júniustól & $14.807 \mathrm{Ft}$ & $1.675 \mathrm{Ft}$ & $16.482 \mathrm{Ft}$ \\
\hline
\end{tabular}

A költségelvü lakbér négyzetméterenkénti mértékét a helyi rendelet szabályozza. E rendelet szerint (ezt a bérleti szerződés is tartalmazza) a vegyes tulajdonú társasházban lévő önkormányzati bérlakás bérlője köteles a közös költség meghatározott részét is a lakbérrel együtt fizetni. K. M. bérleménye ilyen társasházban volt. Ebben a több tucat lakásból álló társasházban minden lakás 21-33 nm-es, 1-1,5 szobás komfortos-félkomfortos, közülük néhány önkormányzati tulajdonban van. A lakbért (és közös költséget) 2016 végéig egy díjbeszedő társaság szedte az önkormányzat megbízásából (a díjbeszedő a beszedett összegeket átutalta az önkormányzatnak, az önkormányzat a beszedett közös költséget továbbutalta a társasháznak). 2017 elejétől az önkormányzat vagyongazdálkodó szervezete közvetlenül szedi a lakbéreket (és közös költségeket).

A lakás - a 2013-as bérleti szerződés szerint - mellékvízmérővel rendelkezett, ezért a lakbérhez csatlakozó víz-csatornadíj fizetését a szerződés nem írta elő, azt ilyen esetben a bérlő maga fizeti egyenesen a szolgáltatónak (szintén a díjbeszedő társaság számlázásával).

A valóságban azonban a közös képviselő a beköltözés óta olyan közös költséget számlázott ki az önkormányzat felé, mintha a lakásban nem lenne önálló mellékvízmérő. Ennek okát nem tudjuk, legfeljebb csak feltételezzük, hogy a meglévö vízóra hitelesítése elmaradhatott. A hiteles vízórával rendelkező lakóknak csupán $100 \mathrm{Ft} /$ hó víz-, csatornadíjat kellett fizetniük. A társasház tényleges vízfogyasztása alapján - a szolgáltatónak fizetendő összegböl a vízórás lakók $100 \mathrm{Ft}$-jait levonva - a teljes fennmaradó összeget a vízórával nem rendelkező lakókra terhelték, havi bontásban. Emiatt K. M. éveken keresztül több közös költséget kellett befizetnie az önkormányzat részére (mely a befizetett közös költséget megküldte a társasház részére). Ezzel párhuzamosan viszont K. M.-nek a szolgáltató felé közvetlenül nem kellett fizetnie, onnan számlákat sem kapott, az órát sem olvasták le stb.

2018 augusztusában K. M. a korábbiaknál magasabb összegü havi lakbér- (és közös költség) számlát kapott (16.102 Ft helyett 17.953 Ft-ról), melyet időben befizetett, majd szintén augusztusban kapott még egy, „különszolgáltatási díjkülönbözet”-röl szóló számlát is (a 2017. 
április - 2018. július közötti időszakra, 16 hónapra vonatkozóan) 32.143 Ft-os fizetési kötelezettségről (ez havi bontásban 2009 Ft plusz terhelést jelent!).

Nem kaptunk felvilágositást arra vonatkozóan, hogy konkrétan milyen elszámolás áll e második augusztusi számla mögött (K. M. az addigi számlákat rendre befizette), ezért csak feltételezni tudjuk, hogy a társasház 2018 tavaszán megemelte a fizetendő közös költséget (ezért emelkedhetett a havonta fizetendő számla összege) és ezzel párhuzamosan a helyi vízmü társaság az éves óraleolvasás keretében megállapíthatta, hogy a ház vízfogyasztása meghaladta a megelőző leolvasáskorit, $\mathrm{s}$ a különbözetet a társasház továbbszámlázta a tulajdonos önkormányzatnak, mely kibocsájtotta a követelést a bérlő felé.

Ezt a 32.143 Ft-os összeget K. M. - az önkormányzat nyilvántartása szerint - akkor nem fizette be, majd csak 2019 elején írják jóvá ezt a számlát. Ugyanakkor sem K. M.-nél sem az önkormányzatnál semmilyen nyoma nincs annak, hogy ezen összeg be-nem-fizetésével kapcsolatban bármilyen felszólítás, vagy egyéb dokumentum keletkezett volna (ezt a követelést sem a 2019. év eleji Felszólítás, sem az ahhoz képest egy hónapon belül megérkező Felmondás nem tartalmazta).

A következő hónapban,

2018 szeptemberében (hó 20 -áig) K. M. nem fizette meg a szeptember havi, immár $17.953 \mathrm{Ft}$ összegü lakbér- (és közös költség) számlát.

Ezt követően a

2018. októberi lakbér- (és közös költség) számlát K. M. ugyan befizette, de a szeptemberi kimaradás miatt a polgármesteri hivatal vagyongazdálkodási irodája

2018 novemberében „szerződés felmondás elötti utolsó fizetési felszólitúst” küldött. A tértivevényes levél érkezéséről szóló Értesítés után azonban K. M. a levelet a postán nem kereste. Az október havi számla befizetését követően azonban

2018 novemberében (hó 20 -áig) K. M. ismét nem fizette meg a november havi, 17.953 Ft összegü lakbér (és közös költség) számlát.

Ezért a polgármesteri hivatal vagyongazdálkodási irodája

2018 decemberében ismét „szerződés felmondás elötti utolsó fizetési felszólítást” küldött. A tértivevényes levél érkezéséről szóló Értesítés után azonban K. M. a levelet a postán ismét nem kereste.

Ezzel együtt K. M. a

2018. decemberi, folyó havi 17.953 Ft összegü lakbér (és közös költség) számlát befizette.

Jelenleg senkitől nem kaptunk választ arra, hogy miért nem fizette be időben a havi lakbért K. M., miért nem (tudta?) átvenni november, majd december elején a Felszólítást, illetve miért nem fizette be az ezt követő időszakban a kettő havi - szeptemberi és novemberi - lakbért (miközben az októberit, decemberit időben befizette). Utólag ezekre a kérdésekre K. M. sem tudott számunkra magyarázatot adni.

Ezek a kérdések azért is merülnek fel nyomatékosan, mert minden „rendetlenség” ellenére (melyről még részletesen szólunk) K. M. feltünően rendben, rendszerezett dossziékban tartotta iratait 
(korábbi középvezetői munkája során is ehhez szokott), s korábban havi fizetési elmaradásai nem voltak.

Egészségügyi dokumentumok alapján tudomásunk van arról, hogy K. M. hosszú évek óta több itt most nem részletezendő -, jellemzően időskori betegséggel küzd, melyek rendszeres gyógyszerszedéssel karbantarthatóak. 2018 őszén azonban egészségi állapota megromlott, háziorvosához fordult, aki ellátta, azonban kórházi kezelésre - mely fizikailag korlátozta volna ügyei intézését - nem került sor.

2019. január elején, 2018. december végén (?) intézkedés történt a lakásban lévő mellékvízmérő hitelesítésére, a helyi vízmü munkatársa ekkor a vízórán mintegy $102 \mathrm{~m} 3$ fogyasztást regisztrált, melyről februárban a vízmü számlát bocsátott ki K. M. nevére (erröl később).

A vagyongazdálkodási iroda

2019 januárjában ismét kiküldte tértivevényesen ugyanazt a „szerződés felmondás elötti utolsó fizetési felszólítást”, melyet decemberében már egyszer kiküldött, de akkor nem lett átvéve - a kettő havi, szeptemberi és novemberi be-nem-fizetésröl, összesen 35.906 Ft-ról.

Ezt az Értesítést K. M., a tértivevényes értesítés tanúsága szerint

2019. január közepén a postán átvette. A vagyongazdálkodási iroda minden ilyen felszólítása 8 napos fizetési határidőt szab meg, ha azon belül kifizetik a hátralékot és ezt bemutatják az Irodának, akkor a felszólítást tárgytalannak tekintik.

Ugyanakkor ezek a „,felmondás előtti utolsó fizetési felszólitás”-ok nem tartalmaznak utalást arra vonatkozóan - mint majd maga a Felmondás -, hogy segítségért a családsegítő szolgálathoz lehet fordulni. Emiatt a családsegítő szolgálat - közvetlenül a Felmondás előtti szakaszban - még semmit nem tud az ügyről, kivéve, ha az érintett tud erről a lehetőségről és él is ezzel.

K. M. a Felszólítás átvételét követő 8 napon belül,

2019 januárjában kifizette azt a 32.143 Ft-os elszámoló számlát, melyet még augusztusban kapott. Azt csupán feltételezhetjük, hogy K. M. fogta a nála lévő nagy összegü csekket és befizette, abban a hiszemben, hogy ezzel elmaradását rendezte. Azonban mivel K. M. erre a nagyobb összegü befizetésre később, megkérdezésekor nem emlékezett biztonsággal, azt sem zárhatjuk ki, hogy ennek az összegnek a jóváírása más módon (valamilyen belső elszámolás keretében) történt.

Azonban, mivel a januárban átvett Felszólítástól eltelt 8 napon belül az abban jelzett szeptember és november havi befizetés nem történt meg, ezért

2019. január végén a vagyongazdálkodási iroda a lakásbérleti szerződést 35.906 Ft összegű lakbértartozás miatt (ez pontosan kettő havi lakbér + közös költség) a következő hónap, tehát február végére - élve a Lakástörvényben szabályozott lehetőséggel - felmondta. Egyben felszólította, hogy a lakást legkésőbb eddig az időpontig ürítse ki és tiszta, rendeltetésszerü használatra alkalmas állapotban adja birtokba a vagyongazdálkodás részére.

A Felmondás tartalmazza azt is, hogy amennyiben a megjelölt időpontig a lakás kiürítésére nem kerítene sort, az Önkormányzat minden külön értesítés nélkül, haladéktalanul intézkedik a peres eljárás megindításáról a lakás kiürítése érdekében (magyarul: a kilakoltatás érdekében).

A Felmondás tartalmazza azt is, hogy a hátralék rendezésében, rászorultság esetén a család- és gyermekjóléti központ családsegítő szolgálata segítséget tud nyújtani. 
A család- és gyermekjóléti központ ekkor értesül K. M. helyzetéről - közelebbröl arról, hogy felmondták határozatlan idejü önkormányzati bérleti szerződését -, mivel a helyi szabályoknak megfelelően:

\subsection{ELSŐ SZAKASZ _ BÉRLŐBÖL HAJLÉKTALANNÁ VÁLÁS}

2019. január végén a Felmondást tájékoztatásul a család- és gyermekjóléti központ (csgyk) is megkapta. A csgyk vezetője azt a csgyk egyik munkatársának ki is szignálta, mint minden ilyen tájékoztatás esetén szokás.

2019 februárjában a csgyk munkatársa ki is ment K. M.-hez, azonban - a későbbi (június végi vagyongazdálkodási irodának megküldött Tájékoztatás szerint - őt ott nem találta, a lakásba ily módon nem juthatott be. A munkatárs, egy Értesítést hátrahagyva - hol és mikor lehet felkeresni a munkahelyén - távozott.

Megjegyzendő, hogy ezen ponton két különböző protokoll ütközhetett egymással:

(a) a vagyonkezelő szabályai szerint a bérleti szerződés kettő havi elmaradás esetén egy hónapos felmondási idővel felmondható, miközben

(b) maga az adósságkezelési eljárás két havi, kis összegü hátralék esetében még el sem indul (ráadásul, K. M. 110.000 Ft-os nyugdíja meghaladja a helyi rendeletbeli jövedelem-plafont, mely alatt adósságkezelés igénybe vehető).

Utóbbi eljárást megerősíti az a folyamatos tapasztalat is, hogy a Felszólítást követően a bérlök döntő többsége - késve ugyan, de - magától rendezi elmaradását, további közreműködésre nincs szükség. (A település lakáskoncepciójában található vonatkozó adatok is ezt a tapasztalatot támasztják alá.)

Legközelebb júniusban vették fel a kapcsolatot K. M.-mel, mintegy négy hónap elteltével.

Miután a vízóra hitelesítését követően 2019. január 1-től a helyi vízmü vette át a víz-csatornadíj beszedését, számlázását, ezért

2019. február elején K. M. kapott egy „Vizközmü-szolgáltatás elszámoló számlát” (február 28-i befizetési határidővel) arról, hogy fizessen be 22.583 Ft-ot egy csaknem négy éves - 2015. február és 2019. január közötti - időszakra vonatkozóan. A csatolt számlarészletezőből megállapítható, hogy a csatornadíjjal együtt összesen ekkor 64. 472 Ft-ot kellett volna K. M.-nek megfizetnie. Ezt az összeget K. M. nem fizette be - nem is értette, mi ez a számla. Így az ilyen díjakat beszedö társaság 2019 áprilisában Fizetési felszólítást küldött, melyre szintén nem történt befizetés.

Az összeg kiszámításának az alapja a vízórán a leolvasáskor regisztrált 102 m3-es vízfogyasztás volt, mely a 2015. februári nullás állás óta keletkezett, $s$ melyről korábban számla nem készült. Februárt követően minden második hónapban (április, június, augusztus) a helyi vízmüvek átalányszámlát állított ki (690Ft víz-, 848 Ft csatornadíjról), azonban a vagyongazdálkodási iroda továbbra is a korábbi lakbér (és vízdíjjal együtt számolt közös költség) összegét számlázta K. M.nek, havi 17.953 Ft-ot, aki ezt az összeget (a Felmondást követően már használati díj címén) márciusban, áprilisban stb. stb. havonta be is fizette.

A vagyongazdálkodási iroda nyilvántartásában majd májusban jelenik meg a változás...

Mivel a január végi Felmondás kapcsán változás nem történt:

egy hónap múlva, 2019. február végén, a Felmondásban foglaltaknak megfelelően $\mathbf{K}$. M. határozatlan idejü bérleti jogviszonya megszünt. Ezzel K. M. jogcím nélküli lakáshasználóvá 
minősült át, a továbbiakban havi lakáshasználati díjat (és ehhez csatlakozó közös költséget) kellett fizetnie - a vizsgált időszakban a használati díj összege megegyezett a lakbér összegével.

Miután K. M. február végéig nem adta át kiürítve a lakást, azért a vagyongazdálkodási iroda

2019. március elején ismét levelet küldött $K$. M. részére, hogy a lakást legkésőbb március 31-ig adja birtokba, hagyja el, különben jogi úton intézkedik erröl az Önkormányzat. A tértivevényes levelet K. M. átvette és maradt a lakásban.

2019. március végén K. M. a 17.953 Ft összegü használati díjat (és közös költséget) idöben befizette.

Mivel letelt a március végi lakáselhagyási (birtokba adási) határidő, ezért a vagyongazdálkodási iroda

2019. áprilisában megkereste az $X$. ügyvédi irodát, hogy immár jogi úton érvényesítse a lakás kiürítése iránti igényét (kilakoltatás) és egyben jogi úton behajtsa az addig felhalmozott kintlévőségét. Az ügyvédi iroda megkeresésének időpontjában a meg nem fizetett díjak összege 71.812 Ft volt, vagyis összesen négyhavi lakbér/használati díj (és közös költség). (K. M. 2018 szeptembere óta minden második hónapban fizetett, egy-egy hónap kihagyásával.)

Ugyanakkor

2019. április első napjaiban K. M. a díjbeszedő társaságtól is kapott egy Fizetési felszólítást, melyben felszólították, hogy a társaságnál a 2018. december közepe és 2019. március közepe közötti időszakra fennálló 64.472 Ft tartozását 8 napon belül fizesse meg. K. M. nem rendezte ezt a tartozását, viszont

2019. április elején befizette a még ki nem egyenlített szeptemberi 17.953 Ft lakbért (és közös költséget), vagy másképpen fogalmazva, ekkori befizetését a szeptemberi elmaradás jóváírására könyvelték, majd ezt követően egy hét múlva befizette az ugyanilyen összegü áprilisi használati díjat (és közös költséget) is.

2019 májusában K. M. a 17.953 Ft összegü használati díjat (és közös költséget) időben befizette.

2019. májusában a vagyongazdálkodási iroda 47.434 Ft-ot jóváírt $K$. M. lakbér- (és közös költség) számláján (a 2017. év eleje és a 2019. május vége közötti időszakra), azzal az indoklással, hogy K. M. a vízóra felszerelése óta közvetlenül a szolgáltatónak (közelebbről a díjbeszedő társaságnak) kellett, hogy fizesse a vízdíjat, ezért az önkormányzat által erre az időszakra tőle korábban beszedett összeget ekkor jóváírták.

A helyi vízmüvek által februárban kiállított számla 64.472 Ft követelést tartalmazott a 2015. februárja óta eltelt időszakra vonatkozóan, ebből a vagyongazdálkodási iroda ugyan 47.434. Ft-ot jóváírt a 2017. január utáni időszakra, arra vonatkozó intézkedésről azonban nem tudunk, hogy a 2015. február és 2017. január vége közötti idöszak kérdését rendezték volna.

A 47.434. Ft-os jóváírásról

2019. május harmadik hetében $K$. M. jóváíró számlát kapott a vagyongazdálkodási irodától (bár ö, elmondása szerint, nem értette, mi ez a számla). Arról nem kapott külön értesítést, hogy ezzel a törvényi elöírásoknak megfelelően - jóváírták mind a novemberi, mind a januári lakbér (és közös költség) tartozását, valamint a februári tartozásának is egy részét.

Így aztán, amikor 
2019. május végén a megbízott ügyvédi iroda elkészítette és beadta a bírósági keresetet, hogy kérje a lakás kiürítését a szeptember és november havi nem-fizetés miatti Felmondás végrehajtása érdekében, K. M. tartozása az önkormányzat felé - a beadott kereset tanúsága szerint is mindösszesen 6.425 Ft volt. Minderröl K. M.-et ekkor nem tájékoztatták.

\begin{tabular}{|c|c|c|c|c|}
\hline Hónap & $\begin{array}{c}\text { Fizetendő } \\
\text { összeg (Ft) }\end{array}$ & Befizetés & \multicolumn{2}{|c|}{ Hátralék (Ft) } \\
\hline \multicolumn{5}{|l|}{2018} \\
\hline január & 16102 & időben befizette & & \\
\hline február & 16102 & időben befizette & & \\
\hline március & 16102 & időben befizette & & \\
\hline április & 16102 & időben befizette & & \\
\hline május & 16102 & időben befizette & & \\
\hline június & 16102 & időben befizette & & \\
\hline július & 16102 & időben befizette & & \\
\hline augusztus & 17953 & időben befizette & & \\
\hline $\begin{array}{l}\text { augusztus - elszámolás - } \\
\text { terhelés }\end{array}$ & 32143 & $\begin{array}{c}\text { 2019. január 23-án fizette be, } \\
\text { írták jóvá }\end{array}$ & & \\
\hline szeptember & 17953 & 2019. április 9-én fizette be & $\begin{array}{c}\text { felmondáskor } \\
\text { hátralékban }\end{array}$ & 17953 \\
\hline október & 17953 & időben befizette & & \\
\hline november & 17953 & $\begin{array}{l}\text { 2019. május 10-i jóváírással } \\
\text { rendezve }\end{array}$ & $\begin{array}{c}\text { felmondáskor } \\
\text { hátralékban }\end{array}$ & 17953 \\
\hline december & 17953 & időben befizette & & \\
\hline \multicolumn{5}{|l|}{2019} \\
\hline FELMONDÁS & & & hátralék & 35906 \\
\hline január & 17953 & $\begin{array}{l}\text { 2019. május 10-i jóváírással } \\
\text { rendezve }\end{array}$ & & \\
\hline február & 17953 & $\begin{array}{l}\text { 2019. május 10-i jóváírással } \\
\text { részben rendezve }\end{array}$ & $\begin{array}{l}\text { megmaradó } \\
\text { hátralék }\end{array}$ & 6425 \\
\hline március & 17953 & időben befizette & & \\
\hline április & 17953 & időben befizette & & \\
\hline május & 17953 & időben befizette & & \\
\hline május elszámolás - jóváírás & 47434 & & & \\
\hline PERESÍTÉS & & & hátralék & 6425 \\
\hline
\end{tabular}

Vagyis, miután áprilisában megbízták az ügyvédi irodát a bírósági kereset elkészítésével, s a peranyag összeállításával egyidőben, május elején jóváírtak K. M. önkormányzati számláján 47.434 Ft-ot - a szabálytalan kettős követelést elkerülendő -, s ezzel jóváírták novemberi, januári és részben februári kintlévőségét is (a szeptemberit már korábban, 2019 áprilisában K. M. kiegyenlítette), ezután maradt a februári, egyébként felmondás utáni, részkövetelés, azaz 6.425 Ft. A kereset beadásáig eltelt időben (március-április-május) K. M. a havi használati díjakat időben befizette.

Adatközlöként a vagyongazdálkodási iroda ekkortól ugyanennek az információnak a birtokában volt. Az önkormányzat jegyzője és polgármestere ugyancsak birtokában lehetett ennek az információnak (arra is tekintettel, hogy az ügyvédi iroda konkrét ügyre vonatkozó megbízását júliusban, saját aláírásukkal pótolniuk kellett a bíróság felszólítására).

Együttmüködés hiányában nem tudtuk megállapítani, így csak feltételezni tudjuk (tekintettel arra is, hogy a májusi 47.434. Ft-os elszámoló számla K. M. saját iratai között szerepelt), hogy a 
családsegítő szolgálat munkatársa, s az intézmény vezetője szintén birtokában lehetett ezen információknak, amikor majd júniusban ismét foglalkoztak K. M. ügyével.

\subsubsection{PANASZRA OKOT ADÓ RENDETLENSÉG_KOSZ_BÜZ KIALAKULÁSA A LAKÁSBAN}

2019 júniusában két alkalommal - elöször e-mailben, majd azt követően levélben is - kereste meg az egyik lakó az önkormányzat jegyzőjét, hogy intézkedését kérje a K. M. lakásában év eleje óta felhalmozott szemét és az ebből eredő - immár a lépcsőház többi lakásában lakókat zavaró - büz megszüntetése érdekében. A levélíró egyéb, korábban jelzett társasházi problémákra is utalt, illetve arra is, hogy ezeket az ügyeket már korábban is jelezték a lakók több „illetékes személy” felé, eredménytelenül. (Egyébként K. M. kapcsolata közvetlen szomszédaival kifejezetten jó volt - mind saját, mind a szomszédok elmondása szerint).

A szomszédok első, e-mailes bejelentésére 1 napon belül reagálva

2019. június második hetében a vagyongazdálkodási iroda egy Felszólítást küldött ki $\mathrm{K}$. M. részére, melyben felszólították környezete tisztán tartására, mert különben a törvény szerint a bérbeadó jogosult lenne a lakás kiürítése iránt intézkedni. Egyben tájékoztatták, hogy július 4-én bérlemény-ellenőrzést kívánnak tartani a lakásban.

Egyben a vagyongazdálkodási iroda tájékoztatást kért a csgyk-tól a januári Felmondás óta történt fejleményekről.

2019. június közepén, a tájékoztatás kérését követő 6. napon - a vagyongazdálkodási iroda megkeresésére - a csgyk vezetője és K. M-mel közvetlenül foglalkozó munkatársa Tájékoztatást küldött az Irodának, melyben beszámoltak arról, hogy a februári sikertelen látogatást követően aznap (vagyis a Tájékoztatás megküldésének napján) ismét felkeresték K. M.-et, és ekkor már a munkatárs bejutott a lakásba.

A helyszíni látogatás során a csgyk munkatársa feljegyzést (Környezettanulmányt) is készített, melyben rögzítette, hogy K. M. lakásában igen nagy mennyiségü szemét, rendetlenség, elhanyagoltság tapasztalható.

A munkatárs tájékoztatta K. M.-et az adósságrendezés módjáról, lehetőségéröl, azonban a feljegyzés szerint K. M. úgy nyilatkozott, hogy nem tart igényt ilyen segítségre, a lakbértartozáson kívül rezsitartozása nincs, $\mathrm{s}$ a hátralékot a maga erejéből is rendezni tudja.

Mivel a munkatárs - fönökei határozott utasítására - nem válaszolhatott kérdéseinkre, s a csgyk vezetője sem nyújtott erre vonatkozó felvilágosítást, ezért jelenleg nincs tudomásunk arról, hogy a munkatárs elvégezte-e ekkor - a helyszínen, illetve a megfelelő helyeken (vagyongazdálkodási iroda, díjbeszedő társaság) - azt a rutinszerü tájékozódást, hogy K. M-nek milyen irányban, mekkora összegü hátraléka van, vagy volt egyáltalán.

Azt tudjuk, hogy K. M. teljesen áttekinthetően, rendben tárolta megkapott számláit. Azt is tudjuk, hogy ezek mindazon információkat tartalmazták ekkor már, melyeket eddig felsoroltunk. Nem tudjuk, hogy a munkatárs ezeket megismerte-e, ezekröl a csgyk-ban referált-e, ezen információk alapján bármilyen lépés történt volna.

Az említett okból, jelenleg nincs tudomásunk arról, hogy a munkatárs ismerte-e és más esetekben alkalmazta-e az éppen ilyen helyzetekre alkotott helyi rendeleti passzust, mely szerint:

„,Akinek a bérleti szerzödése a határozott idő elteltével dijhátralék fennállásával szünik meg, vagy dijhátralék miatt a bérbeadó a bérleti szerzödést felmondja, annak kérelme alapján a ... Bizottság javaslatának figyelembevételével a polgármester engedélyezheti legfeljebb egy éves határozott idöre szóló ... bérleti szerzödés megkötését a jogcím nélkül használt lakásra." (település 
Önkormányzata képviselő-testületének önkormányzati rendelete az Önkormányzat tulajdonában álló lakások és nem lakás célú helyiségek bérbeadásának feltételeiröl.) Hiszen ennek megfelelően a 6.425 Ft-os hátralék kiegyenlítése, illetve a díjbeszedő társaság elszámoló számlájában jelzett összeg tisztázása, majd részletfizetése mentén kézenfekvő lett volna az adósságrendezés rövid úton történő lebonyolítása.

Jelenleg nincs információnk arról sem, hogy a csgyk a lakás, illetve a lakó állapotáról ekkor tájékoztatta-e az Önkormányzat másik illetékes szervezetét, a szociális szolgálatot.

Azonban

2019 júniusának harmadik hetében a szociális szolgálathoz is megérkezett a lakói panasz, hogy K. M. lakásában igen nagy rendetlenség, bűz, kosz stb. van, valamit tenni kellene. (A szociális szolgálat foglalkozik a kerületben - többek között - az idősgondozással, házi segítségnyújtással, átmeneti, vagy tartós elhelyezéssel.)

2019 júniusának utolsó hetében, a megkeresést követő 3. napon a szociális szolgálatnak a házi segítségnyújtás megszervezésével foglalkozó munkatársa ki is ment a lakásra, hogy felmérje mind a lakó, mind a lakás állapotát, milyen intézkedésre van szükség. A szociális szolgálat munkatársa a lakás állapota alapján indokoltnak látta ún. szociális takarítás elvégzését a lakásban, egyben K. $\mathrm{M}$. állapota alapján indokoltnak látta a rendszeres házi segítségnyújtást is. $\mathrm{K}$. M. mindkét felajánlott segítséget pozitívan fogadta.

Egy ilyen takarítás megrendelését alaposan indokolni kell, ennek érdekében az elöírások szerint fényképfelvételek is készültek a lakásban található állapotokról.

Mivel köztudomású, hogy - elsősorban idős, beteg emberek esetében - előfordul a lakás extrém elhanyagoltsága (vagy éppen a krónikus gyüjtögetés), ezért a szociális szolgálat 2019. évi költségvetésében beterveztek forrást az ún. szociális takarításokra. Ennek a keretnek a terhére a szolgálat vezetője kereshetett közremüködő takarító céget, majd az önkormányzat gazdasági irodájának jóváhagyását követően megrendelhette a munkálatokat. Ez a takarítás ilyen esetekben egyben egyfajta elöfeltétele is annak, hogy a tervezett házi segítségnyújtás biztonságos körülmények között megkezdödhessen.

2019. július első napjaiban a szociális szolgálat által megbízott takarító vállalkozó elvégezte a szociális takarítást, melyet éppen

2019. július első hetében - még a júniusi Felszólításban beígért - bérlemény-ellenőrzés követett. A bérlemény-ellenőrzés során a vagyongazdálkodási iroda munkatársai meggyőződhettek arról, hogy a takarítás eredményes volt, a lakásban rend és tisztaság van.

Valójában a vagyongazdálkodási iroda munkatársai egy előkészített birtokba vételi Jegyzőkönyvvel érkeztek. Csak emlékeztetőül: a vagyongazdálkodási iroda írta jóvá három héttel ezelött K. M. szeptemberi, novemberi és részben februári tartozását, ott tartották nyilván, hogy ekkor 6.425 Ft tartozása áll fenn az önkormányzat felé, és ott készítették elö a május végén az ügyvédi iroda által beadandó bírósági kereset rájuk vonatkozó részét is. Valamint a vagyongazdálkodási iroda köti meg mindazon bérleti szerződéseket is, melyek a hátralék miatt felmondott jogcím nélkülieket érintik az említett rendelet szerinti bizottsági, majd polgármesteri jóváhagyást követően.

Az ekkor elkészült birtokba vételi Jegyzőkönyvben - amellett, hogy rögzítették, hogy a 20 nm-es lakás szobájában fütőberendezés nincs, a fürdőszobában kád, zuhanyozó, mosdó nincs - a 
megjegyzés rovatban megállapították, hogy „A lakás rendezett, ott lomot nem találtunk. $K$. M.-et tájékoztattuk a felmondott bérleti szerzödés tényéröl és felhívtuk az önkéntes lakás birtokba adásra 2019. július végéig."

A Jegyzőkönyvön szerepel K. M. - minden egyéb iraton szereplő aláírásától markánsan eltérő aláírása is.

(A vagyongazdálkodási iroda területi felosztásban dolgozik, így K. M. bérleményével folyamatosan ugyanaz a munkatárs foglalkozott évtizedek óta. A vagyongazdálkodási iroda munkatársa müködött közre még a 2012-2013-ban lebonyolított lakáscserében is, amikor K. M. a korábbi nagy lakásból történő szétköltözéskor ide került, de már azt megelőzően is ismerték egymást - és K. M. állítása szerint kifejezetten nem jó viszonyban voltak.)

A Jegyzőkönyv aláírását követő héten, a

2019. július 2. hetében a házi gondozást szervező munkatárs - vezetői konzultációt követően: a lakó ellátásra szorul, együttműködő, pozitívan fogadná a segítséget - elkezdte K. M. házi gondozásba vételének az előkészítését. Ismét felkereste $K$. M.-et, vele együttmüködve elkezdődött a szükséges iratok beszerzése (pl. a TAJ kártyát nem találták, ennek hiányában a KENYSZI-be ekkor még nem tudták felvinni, s így hivatalosan házi gondozásba venni). Az ilyenkor szükséges háziorvosi vizsgálatra - az orvos szabadsága miatt - ekkor nem tudtak sort keríteni.

Jelenlegi információink szerint az ezt követő héten, vagyis a

2019. július 3. hetében válhatott nyilvánvalóvá a szociális szolgálat házi segítségnyújtás előkészítésén dolgozó munkatársainak - mivel az iratok pótlásához a csgyk segítségét is kérni kellett -, hogy a csgyk is foglalkozik K. M. ügyével.

Ahogy a csgyk munkatársa is jelezte júniusi Környezettanulmányában (munkahelyi feljegyzésében), hogy a lakásban nagy mennyiségü szemét, kosz található (az ezzel kapcsolatos lépések mérlegelése azonban a szociális szolgálat illetékességébe tartozik), úgy a Szociális Szolgálat munkatársa is jelezte június utolsó hetében készített Környezettanulmányában, hogy K. M.-nek lakbérhátraléka van (az ezzel kapcsolatos lépések azonban a csgyk illetékességébe tartoznak).

A két szervezet párhuzamos időben, de különböző irányban tett lépéseinek az észlelését követően a vezetők Esetmegbeszélőt hívtak össze még ugyanezen a héten, tehát július utolsó hetében.

2019. július utolsó hetében az Esetmegbeszélőn részt vettek a csgyk és a szociális szolgálat vezetői, valamint az aktuálisan érintett ügyfelekkel foglalkozó munkatársak. Itt tisztázhatták, hogy a szociális szolgálat nem tudott arról, hogy K. M. a lakás elhagyása elött állt, amikor a szociális takarítás megrendelésével megkeresték őket, azt megszervezték, és elkezdték K. M. házi gondozásba vételének az előkészítését. Ugyanakkor a család- és gyermekjóléti központ tájékoztathatta a kollégákat, hogy ilyen esetekben (lakásbérleti szerződés felmondása) a helyi szabályok szerint ők illetékesek eljárni, adott esetben akár valamilyen megoldást is keresni az érintett részére.

Az ilyen esetekben, amikor a Felmondásról a csgyk Tájékoztatást kap a vagyongazdálkodási irodától (szükség esetén azt követően is Tájékoztatást kérnek a csgyk-tól) a csgyk vezetője határozza meg - több szempont együttes mérlegelése alapján -, hogy milyen irányban induljanak el. Csak példaképpen (kiskorúakat nem érintő esetekben): (a) adósságkezelés a lakhatás megtartása mellett, vagy (b) a kilakoltatással párhuzamosan intézményi ellátás a helyi hajléktalanellátó szervezet bevonásával, vagy (c) az érintett tájékoztatása a kilakoltatást követő hajléktalan-ellátási lehetőségekről. 
K. M. esetében a csgyk vezetőjének a döntése egyértelmüen arra irányult, hogy a vagyongazdálkodási iroda munkatársai által - a július első hetében történt látogatásuk során előirányzott július végi határidőig keressenek részére egy elhelyezési lehetőséget a hajléktalanellátáson belül.

Ebben az esetben ez a vezetöi döntés született, holott a helyi gyakorlat az adósságrendezésre és a lakás megtartására is kifejezetten lehetőséget nyújtott. (Ahogy ezt számos önkormányzati dokumentum, az éppen ebben az időben készült képviselőtestületi előterjesztés is a helyi lakáskoncepció alapján 2018. közepétől 2019. május végéig megtett lépésekröl tartalmazza: „,Azoknak a lakáshasználóknak, akiknek a határozott időtartamú szerzödése díjhátralékkal szünt meg, vagy a bérleti jogviszonyukat az Önkormányzat tartozás miatt felmondta, lehetöséget adunk a hátralék rendezését követően jogcím nélküli lakáshasználatuk rendezésére új, egy éves idötartamra szóló bérleti szerződés megkötésével. A beszámoló időszakában 21 esetben javasolta a szociális, egészségügyi, esélyegyenlöségi bizottság a polgármesternek határozott idejü bérleti szerzödés megkötését a korábbi bérlökkel. A bérleti szerzödések aláirása minden esetben megtörtént.

Több esetben fordult elö az együttmüködés szándékát méltányolva, hogy a jogerös itélet birtokában sem kezdeményeztük a végrehajtási eljárás lefolytatását, mert a volt bérlö az Önkormányzattal szemben fennálló valamennyi fizetési kötelezettségét teljesitette, a közüzemi dijak rendezésére pedig a közmüszolgáltatókkal megállapodott. Ezekben az esetekben is lehetővé tettük határozott idejü szerzödés megkötését."

Ennek az önkormányzati beszámolónak a tükrében nyilvánvalóan fölmerül a kérdés, hogy az ügynek ebben a szakaszában - amikor még a peres eljárás ideje alatt bőven lett volna lehetőség az igencsak kis összegủ adósság rendezésére - miért ez a vezetői döntés született ebben az esetben. A vezetői döntésnek megfelelően

2019 júliusa során a csgyk munkatársa - a hajléktalan emberekkel foglalkozó diszpécserszolgálat feljegyzése szerint - többször telefonon megkereste a diszpécserszolgálatot, kezdetben a szóba jöhető szállások elérhetősége érdekében, majd a konkrét elhelyezési lehetőségek megszervezése érdekében. Több forrás is megerösítette a diszpécserszolgálat azon információját, mely szerint a csgyk munkatársa emellett, ebben az időszakban konkrét magánbérleti lehetőséget is, valamint idősotthoni elhelyezési lehetőséget is keresett és talált. Információnk szerint tájékozódott egy idősotthonnál is, azonban itt helyhiány miatt nem jutottak tovább.

A diszpécserszolgálatnál az ügyek folyamatos kezelése érdekében minden hívást és annak rövid tartalmát rögzítik, így megállapítható, hogy

2019. július 3. hetében, az említett, intézményközi Esetmegbeszélést megelőző napon is, majd az Esetmegbeszélést követő napokban,

2019. július utolsó hetében is a csgyk munkatársa felvette a kapcsolatot a diszpécserszolgálattal, hogy K. M. mielőbbi hajléktalanszállón történő elhelyezéséről gondoskodhasson. Az erről szóló egyeztetések során a diszpécserszolgálat ügyeletese kifejezetten felhívta a csgyk munkatársának a figyelmét arra, hogy a hajléktalanellátásban való elhelyezés megszervezését megelőzően indokolt volna meggyőződni arról, hogy nem lehetséges-e az ügyfél kilakoltatásának és hajléktalanná válásának a megelözése, amihez segítséget is felajánlott, amivel azonban a csgyk munkatársa vezetői döntésre hivatkozva - nem élt. 
Aznap a csgyk munkatársa K. M.-mel együtt felkereste az idős hajléktalanok átmeneti szállóját, mely tetszhetett K. M.-nek, azonban üres féröhely nem volt, a település átmeneti szállóinak felvételi csoportjához irányították őket.

A csgyk munkatársa - szintén aznap - K. M.-mell együtt felkereste a település átmeneti szállóinak felvételi csoportját - annak ellenére, hogy korábban telefonon itt is tájékoztatták, hogy ilyen esetben először a házi segítségnyújtás, vagy éppen az „albérlet”, vagy ha szükséges, akkor az idősotthoni elhelyezés lehetőségeit kellene körüljárni. Egyben tájékoztatást adtak arról is, hogy a hajléktalanok átmeneti szállójára történő jelentkezéshez is szükség van egyes iratok pótlására, valamint háziorvosi igazolásra.

Az Önkormányzat szociális osztálya augusztus végi levele szerint szintén

2019. július utolsó napjaiban a csgyk munkatársa és K. M. közösen felkerestek egy egyházi idősotthont, ahol írásos Felvételi kérelmet nyújtottak be, de ott - részben az iratok és a szükséges vizsgálatok hiánya miatt - még váró listára sem lehetett felvenni. Azonban a július végére megcélzott lakáselhagyási határidő miatt az ilyen irányú munkálatok helyett a rövid úton történő hajléktalan-szállásra költöztetés lett előirányozva.

Közben,

2019. július utolsó napjaiban $K$. M. egyik szomszédja emailben egy érdekvédő szerveződéshez fordult, azzal, hogy „egy idős, beteg nénit” ki akarnak rakni a lakásából egy hét múlva, ennek megelőzéséhez segítségre lenne szükség.

2019. július utolsó hetében a csgyk munkatársa - a hajléktalanellátóktól kapott információink szerint -, időpont-egyeztetést követően, elkísérte K. M.-et egy civil hajléktalan-ellátó felvételi csoportjához, hogy hajléktalanszállóra történő felvételét kérjék. A Kérelmet ugyan kitöltötték, azonban K. M. aláírása azon nem található.

A civil hajléktalanellátó ugyan kapott tájékoztatást arról, hogy a diszpécserszolgálat közremüködésével az adósságkezelő munkatársat és K. M.-et beszélgetésre várják négy nap múlva, július utolsó napjaiban, ügye rendeződéséig hajléktalanok (idős)otthoni elhelyezése kapcsán, azonban erről a szálló ügyeletes munkatársai nem értesültek.

A civil hajléktalanellátó ügyeletes munkatársai abban nem müködtek együtt, hogy K. M. meg is tekinthesse a számára felajánlott hajléktalanszállást, ezzel együtt ekkor elkészítették K. M. hajléktalanszállóra történő Felvételi kérelmét (is), azzal, hogy fel tudják venni az átmeneti szállóra. Minderről a csgyk munkatársának - a helyben szokásos munkarendnek megfelelően - tájékoztatnia kellett a vezetőjét, aki végül az elhelyezési lehetőségek kiválasztásában kompetens.

A vagyongazdálkodási iroda pedig - a júliusi bérlemény-ellenőrzéskor rögzített július végi határidőnek megfelelően - kitüzte a tényleges birtokba adás - birtokba vétel lebonyolításának az időpontját a határidőt megelőző napra.

2019. július utolsó napjaiban, az érdekvédő szerveződéshez befutott lakossági bejelentés alapján a szervezet munkatársai lakásában felkeresték K. M.-et, hogy az ügyben tájékozódjanak. A lakásban rendet és tisztaságot találtak, K. M.-mel részletesen elbeszélgettek, ő hozzájárult a vonatkozó dokumentumok kezeléséhez és megerősítette, hogy az érdekvédő szerveződés segítségét kéri.

2019. július végén, a határidőt megelőző napon a vagyongazdálkodási iroda illetékes munkatársai - ugyanazok, akik a júliusi bérlemény-ellenőrzéskor is ott jártak, s egyikőjükkel, $\mathrm{K}$. M. elmondása szerint, hosszú évek óta igen rossz a kapcsolata - megjelentek K. M. lakásánál. K. 
M. és a csgyk munkatársa egy sport táskába pakolták a gyógyszereit, legszükségesebb holmijait. K. M. a lakás kulcsát a helyszínen átadta a vagyongazdálkodási iroda munkatársának.

Az önkéntes birtokba adással K. M. - határozatlan idejű önkormányzati bérlői jogviszonyának megszüntét követő - jogcím nélküli lakáshasználói státusza jogszerüen megszünt, így ún. kilakoltatásra nem is kellett sort keríteni (bár az ezt célzó keresetet május végén beadták a bírósághoz).

Ezzel az a fajta esetkezelési irány teljesült, mely szerint nem kell a kilakoltatást megvárni, nem kell $a z$ érintettre végrehajtót, rendört küldeni és így elkerülhetö a végrehajtás nagyon megalázó élménye.

A vagyongazdálkodási iroda munkatársai a birtokba vételi Jegyzőkönyv megjegyzés rovatában rögzítették, hogy „Volt bérlö a mai napon a lakást átadta, ingóságait a lakásban hagyta. Volt bérlönek 8 napon belül szükséges a fenti óraállásokig a közmü nullás igazolást bemutatni. Az ingóságok elszállitására 30 nap után kerül sor."

A Jegyzőkönyvet K. M. aláírta - elmondása szerint ekkor teljesen kiborult, ,se kép, se hang” -, majd a csgyk munkatársával együtt elindultak a civil szervezet hajléktalanszállójába.

\subsection{MÁSODIK SZAKASZ _ AZ ELSŐ LAKÁSNÉLKÜLI NAPOK}

2019 júliusának egyik utolsó napján, megérkezésüket követően az átmeneti szállón a K. M.-nél lévő - a havi lakbér többszörösét kitevő - készpénzt értékmegőrzőbe helyezték, azonban a szálló dolgozói a rendszeres gyógyszerezést - az előírásoknak megfelelően - nem vállalták, arról egy ilyen intézményben kinek-kinek magának kell gondoskodnia. Itt derült ki K. M. számára, hogy nem csak idősek laknak a szállón, s nem egyedül lakhat majd egy szobában, sőt - a csgyk kérésétől eltérően - a szobában sem csak idősek alszanak.

K. M. csupán egy éjszakát töltött ezen a szállón,

2019. július végén, reggel innen - dolgai hátrahagyásával - ismeretlen helyre eltávozott. Ezért a szálló munkatársai elkezdték keresni a mentőszolgálatnál (volt-e ilyen szállításuk), a diszpécserszolgálatnál. Mindez eredménytelen maradt, ezért - információink szerint - a rendőrségnél is bejelentették az eltünést.

Mint másnap kiderült, K. M. arra a településre ment, ahol született és felnőtt, s ott úgy elesett, hogy a mentőket kellett kihívni, kórházba szállították, fejsérülése miatt CT-vizsgálatot is lefolytattak, befektették.

Miközben „mindenki kereste” K. M.-et, de nem találták

2019. augusztus első napjának reggelén a diszpécserszolgálat is kereste $K$. M.-et a mentőszolgálatnál, így tudomásukra jutott, hogy előző nap kórházba szállították. A kórház felkeresésekor azonban kiderült, hogy K. M. onnan is eltávozott aznap reggel.

Ezzel párhuzamosan a diszpécserszolgálathoz beérkezett a csgyk vezetőjének telefonja, aki arról tájékoztatta a diszpécserszolgálat munkatársát, hogy tudomása szerint K. M. a település piacán szokott tartózkodni ebben a napszakban, talán ott megtalálják, azonban a csgyk-nak nincs kapacitása ahhoz, hogy az ö munkatársuk ott keresgéljen.

Közben az érdekvédő szerveződés munkatársai elindultak K. M. lakásához, ahova médiastábokat is hívtak, hogy tájékoztassák őket a „kilakoltatásról”. A településen véletlenül összefutottak az egyházi utcai szolgálat munkásaival, akik szintén K. M.-et keresték - de nem találták. 
Azonban K. M. - miután, elmondása szerint, felkereste a lakása közelében lévő, megszokott étkezdéjét - váratlanul megjelent saját volt-bérleményénél, éppen akkor, amikor a tv-stábok és az érdekvédő szerveződés ott forgattak a lakás, a ház előtt. Ekkor készültek róla felvételek, illetve készült vele rövid interjú.

Az interjút követően az érdekvédő szerveződés emberei autóval elkísérték K. M.-et a diszpécserszolgálat vezetőjéhez, hogy a további elhelyezés körülményeiről gondoskodjanak. A diszpécserszolgálat vezetője - miután K. M. a hajléktalan átmeneti szállóra visszatérni nem akart, illetve a diszpécserszolgálat által felkínált ideiglenes elhelyezést elfogadta - egyeztetést követően biztosította K. M. idősotthoni ellátását egy hajléktalanszálláson. Erről az ilyenkor szokásos rendnek megfelelően tájékoztatta az elhagyott átmeneti szállót.

Vagyis

2019. augusztus elejétől miután két nappal azelőtt átadta lakása kulcsát, $s$ aznap éjjel a civil szervezet átmeneti szállóján aludt, majd onnan eltávozva, balesetet szenvedve, a következő napon kórházban kezelték, a rákövetkező naptól folyamatosan, mindmáig K. M. egy hajléktalanok (idősek) otthonában lakott/lakik, ott idősotthoni ellátásban részesült, gyógyszerezése is megoldódott és a szükséges iratpótlási és orvosi vizsgálatokat is lebonyolították.

Így várta ügyének megoldását, miközben, még ugyanezen a napon,

\subsection{HARMADIK SZAKASZ _ KOMMUNIKÁCIÓ A MÉDIÁN KERESZTÜL, MERRE VAN AZ ELŐRE?}

2019. július végén adott hírt Média1 arról, hogy egy idős beteg asszonyt utcára tettek $40.000 \mathrm{Ft}$ tartozás miatt.

2019. augusztus legelején (MÉDIA felület) az Önkormányzat - az előző napi Médial-en megjelent hírre reagálva hivatalos közleményt adott ki, egyben Helyreigazítási kérelemmel fordult a Média1 szerkesztőségéhez.

Szintén ezen a napon a Média2 ugyancsak arról írt, hogy idős, beteg nénit tettek utcára 40 ezer forint miatt, és megszólaltatta a civil szervezet intézményvezetőjét, aki arról nyilatkozott, hogy ők az elhelyezést megelőzően jelezték, hogy nem biztos, hogy az általuk fenntartott hajléktalanok átmeneti szállása volna a „legjobb megoldás”. A Média3 is lehozta az aznap készített beszámolóját.

2019. augusztus elején (MÉDIA) az Önkormányzat előző napi Helyreigazítási kérelmére reagálva az érdekvédő szerveződés az online felületén hosszabb írásban cáfolta az Önkormányzat állításait, és ennek részeként egy rövid interjút is közölt K. M.-mel, amiben K. M. arról számol be, hogy ö nem „önkéntes” birtokba adásként élte meg a július 30-án történteket.

Ugyanezen a napon,

2019. augusztus első napjaiban egy közösségi médiacsoportban intenzív polémia indult az üggyel kapcsolatban, mely hozzájárult a szakmai szervezet néhány nappal későbbi lépéséhez.

2019. augusztus elején (MÉDIA) a Média 2 arról tudósított, hogy már több mint ezren írták alá azt a petíciót (levelet), melyben kérik K. M. visszaengedését lakásába. Egyben arról is tudósítottak, hogy az Önkormányzat szociális otthoni elhelyezést keres K. M. részére.

2019. augusztus első hetében (MÉDIA) az érdekvédő szerveződés közleményt tett közzé, amelyben arról számolt be a nyilvánosság elött, hogy már 1200-an küldtek levelet a polgármesternek, és K. M. több szomszédja is aláírásával támogatta azt a kérelmet, hogy az érintett visszatérhessen az otthonába, egyben személyes konzultációt kezdeményeztek a polgármesterrel 
az ügy megoldásáról. Ehhez helyi önkormányzati képviselők és más influencerek közbenjárását is kérték.

A polgármester - sajtóreferensén keresztül - azt a választ adta, hogy kész a személyes konzultációra, amennyiben előzőleg az érdekvédő szerveződés nyilvánosan bocsánatot kér a közreműködő szolgálatok „,megrágalmazott munkatársaitól”.

Ugyanezen a napon a Média4 is írást közölt, melyben azt írták, hogy már 1200 ember kéri az önkormányzatot, hogy engedje vissza otthonába a kilakoltatott idős nőt.

2019. augusztus első hetében a szakmai szervezet közleményt adott ki a honlapján és a közösségi média oldalán, hogy ad hoc tényfeltáró munkacsoportot hozott létre, melynek célja a történtek sok szempontból történő megismerése és tényszerü leírása, és ezzel vette kezdetét a jelen vizsgálat.

A szakmai szervezet egyben közölte, hogy a tényfeltáró munkacsoport vizsgálódása eredményeit írásban rögzíti és 2019. augusztus végén, a szervezet honlapján és közösségi médiaoldalán nyilvánossá teszi - természetesen a személyes adatok védelmét biztosítva. A szakmai tanulságok levonása és megbeszélése érdekében 2019 szeptemberében nyilvános szakmai fórum szervezését ígérték, amellyel lehetőség nyílik a történtekkel kapcsolatban felmerülő szakmai kérdések megvitatására.

Ugyanezen a napon az érdekvédő szerveződés a polgármesternek küldött válaszlevelében vállalta, hogy megköveti mindazokat, akik úgy érezhetik, hogy megrágalmazták öket, ha az önkormányzat kilátásba helyezi K. M. visszaköltözésének a lehetőségét a lakásba. A polgármesteri kabinet munkatársa erre azzal válaszolt, hogy szeretnék felvenni a kapcsolatot K. M.-mel, a szükséges vizsgálatok elvégzése érdekében. Az érdekvédő szerveződés válaszként megerösítette - mindezen feltételek mellett - a személyes konzultációra irányuló kérését. Ugyanakkor az önkormányzat megbízásából - a már említett - X. ügyvédi iroda is levélben megkereste az érdekvédő szerveződés munkatársait azzal, hogy adják meg K. M. elérhetőségét, tartózkodási helyét a gondozási szükséglet-felméréshez, valamint végleges elhelyezéséhez, az elhelyezésének megoldásához.

2019. augusztus első hetének végén (MÉDIA) a Médial ismét foglalkozott az üggyel, melyben arról is tudósított, hogy vizsgálat indul a 80 éves K.M. lakhatási ügye miatt.

2019. augusztus második hetének elején (MÉDIA) a település polgármestere videót adott közre saját közösségi média oldalán. Ebben a polgármester kész tényként közölte, hogy hajléktalanszállás helyett idősotthoni elhelyezés áll K. M. rendelkezésére, ugyanakkor „keresik M.-et”, nem tudják, hol tartózkodik, de várják szeretettel.

2019. augusztus első hetében a csgyk munkatársa ismételten megkereste az egyházi idősek otthonának vezetőjét K. M. soron kívüli, azonnali elhelyezése ügyében, akinek a szándékairól, állapotáról az otthon vezetője semmit nem tudott. Ezért az intézményvezető az érdekvédő szerveződésnél érdeklődött, mivel a csgyk munkatársa ezt az elérhetőséget adta meg számára.

Ezzel párhuzamosan, az önkormányzat megbízásából az X ügyvédi iroda ismételten megkereste levélben az érdekvédő szerveződés munkatársait, hogy adják meg K. M. elérhetőségét, tartózkodási helyét a gondozási szükséglet-felméréshez, valamint végleges elhelyezéséhez, az elhelyezésének megoldásához.

2019 augusztusának második hetében K. M. hozzájárult ahhoz, hogy - tartózkodási helye megadásának mellőzésével - a szállását fenntartó alapítvány postacíme legyen megadva 
elérhetőségeként. K. M. írásban nyilatkozott az ellátását biztosító szociális segítőknek, hogy nem kívánja a hollétét megosztani a nagyközönséggel. Ezt követően az érdekvédő szerveződés ismételten tájékoztatta az érdekelteket, hogy K. M. elhelyezéséröl a diszpécserszolgálat gondoskodott, elérhetősége így megoldható.

2019. augusztus első felében hajléktalanellátó szervezetek közös Közleményt tettek közzé. Ebben hangsúlyozzák, hogy a hajléktalanellátás keretében biztosítható elhelyezés nem teszi megengedhetővé a családok, emberek otthonukból történő kilakoltatását. Kiemelik azt is, hogy a hajléktalanokkal foglalkozó szolgáltatások és intézményrendszer a hajléktalan élethelyzetek megszüntetését tekintik céljuknak, és semmiképpen nem az emberek, családok hajléktalanná válásának segítését.

2019. augusztus második hetében a csgyk vezetője levélben fordult a diszpécserszolgálat vezetőjéhez K. M. elérhetőségét tudakolva, idősotthoni elhelyezésének ügyintézése érdekében, az érdekvédő szerveződéstől kapott azon információra hivatkozva, hogy K. M. elhelyezéséről a diszpécserszolgálat gondoskodott.

Ugyanezen a napon K. M. az addig lakott krízisszobából átköltözött - a szükséges és megfelelő eredményeket mutató orvosi (háziorvosi, pszichiátriai, szemészeti) vizsgálatokat követően - a hajléktalanok idősek otthonába, miután kérvényezte ideiglenes elhelyezését mindaddig, amíg lakhatási ügye megoldódik. Erről a rendszeresített Megállapodást megkötötte. Jelenlegi szociális munkás segítője szerint tudna magáról gondoskodni, ehhez azonban rendszeres segítségre és odafigyelésre is szüksége lenne.

Másnap,

2019. augusztus második hetének végén a diszpécserszolgálatot müködtető alapítvány igazgatója levélben tájékoztatta a csgyk vezetőjét a K. M. által megadott elérhetőségről.

2019. augusztus közepén (MÉDIA) a település polgármestere sajtótájékoztatót tartott az ügyről, s ennek előzeteseként ismét videót adott közre saját közösségi média oldalán, amelyben többek között megismétli a korábbiakat, az idősek otthoni elhelyezés lehetőségét, valamint, hogy keresik M.-et. (Ekkor már K. M. elérhetősége napok óta nyilvános volt, a csgyk vezetője személyesen telefonon tájékozódott erről a diszpécserszolgálatnál.)

2019. augusztus utolsó hetében kereste meg először, ténylegesen, levélben az önkormányzat (a szociális osztály vezetője) K. M.-et, részben a lakásügyére vonatkozó, K. M. által korábban megkért, iratok megküldésével, részben az idősotthoni elhelyezés igénybevételének ismételt felajánlásával.

\subsection{NEGYEDIK SZAKASZ _ VISSZA AZ ÖNKORMÁNYZATHOZ}

Időközben az adatigénylések eredményeképpen megismerhetővé váltak a K. M. ügyében rendelkezésre álló hátralékos kimutatások, jóváírások, a számlakövetelésekre és befizetésekre vonatkozó nyilvántartások. Ezek feldolgozásra és elemzésre kerültek.

2019. szeptember második hetében a helyi képviselőtestületi ülésre egy független képviselő Sürgösségi indítványt nyújtott be, melynek határozati javaslatai felhívták a polgármestert, hogy 
„,a) vizsgálja meg, hogy ... felszólitás közlésekor fennállt-e a bérlőnek tartozása az önkormányzat felé,

b) amennyiben a felszólitás közlésekor nem állt fenn a bérlönek tartozása, tegye meg a törvényesség helyreállitásához szükséges intézkedéseket,

c) irányitási jogkörében vizsgálja meg, hogy ... a bérlakásból való távozását megelözöen a családés gyermekjóléti központ a jogszabályoknak és szakmai szabályoknak megfelelöen járt-e el, ennek során nyújtott-e megfelelö szociális segitömunkát és tanácsadást számára, megadta-e neki a szükséges segitséget a bérleti jogviszonya rendezéséhez és az ahhoz szükséges ügyintézéshez, továbbá nyújtott-e felvilágositást számára arról - a hajléktalanellátó intézménybe való elhelyezése elött -, hogy kizárólag egy esetleges végrehajtási eljárásban kényszerithetö az otthona elhagyására;

d) vizsgálja meg, hogy hány esetben, milyen hosszú idöszakban és mekkora összegben fordult elö, hogy az önkormányzati bérlakások bérlöivel jogosulatlanul fizettetett az önkormányzat dijat vagy költséget,

e) aza)-d) pontok szerinti vizsgálat eredményeiröl, valamint a megtett intézkedésekröl tájékoztassa a Képviselö-testületet."

Határidö: 2019. október eleje

Az indítványt a testület elfogadta.

2019. szeptember második hetében az érdekvédő szerveződés reagált a képviselő-testületi ülésen történtekre és egyben reményüket fejezték ki, hogy K. M. immár visszaköltözhet korábbi bérleményébe.

\section{A tényfeltáró vizsgálat szeptember közepén lezárult.}

\section{A MUNKACSOPORT MEGÁLLAPÍTÁSAI}

\subsection{SZOCIÁLIS SEGÍTÉS _ ÉRDEKVÉDELEM}

3.1.1. Talán a leginkább tanulságos az a sokféle szerep, mely megjelenik a szakmában dolgozók részéről egy-egy ilyen ügymenet kapcsán. A felszínen mintha kitapintható feszültség húzódna az állami-önkormányzati-egyházi fenntartású, függöségben lévő szervezetekben dolgozók és az ezektöl független érdekvédők között, a segítés és az érdekvédelem között.

Magát a tényfeltáró vizsgálatot is részben ez a feszültség provokálta életre, nevezetesen, hogy „már az érdekvédök is bennünket támadnak, védjük meg a szakmánkat” a valós tények megismerése és megismertetése segítségével. Ez részben reakció volt arra, hogy az érdekvédők már első nyilvános megszólalásukban a szociális szakma Etikai Kódexének be-nem-tartását emlegették, és súlyos következményeket helyeztek kilátásba, ha kiderül, hogy valaki hibát követett el munkája során.

3.1.2. Ennek a - talán csak lelki szemben állásnak a - fényében igencsak tanulságos, elgondolkodtató, hogy

a. az érdekvédők körében kizárólag olyan, szociális szakmában hosszú évek (vagy éppen évtizedek) óta dolgozó segítők, de minimum erre jogosító felsőfokú végzettséggel rendelkező szakemberek müködtek közre K. M. ügyének intézésében, akik maguk is fóállásban önkormányzati, vagy éppen civil segítő szervezetek alkalmazottai, munkaidőn kívül önkéntes 
aktivistái (egyetlen személy kivétel ez alól, aki K. M. szomszédjaival vette fel a kapcsolatot az események során),

b. a szóban forgó ügyben közremüködő beosztott intézményi szakalkalmazottak egy része, illetve kollégáik, volt kollégáik keresték és használták is az érdekvédelem érdekében annak lehetőségét, hogy felvegyék a kapcsolatot az „érdekvédőkkel”, s tőlük segítséget kérjenek, támogatást kapjanak (már a lakásból való kikerülést megelőzően is, majd a további események során is, egészen a tényfeltáró vizsgálat lezárultáig).

3.1.3. Természetesen azt is tanulságként, ha nem is újdonságként rögzíthetjük, hogy a beosztott alkalmazottak - figyelemmel a kialakult helyi, segítő intézményeken belüli viszonyokra megkereséseiket „az érdekvédök” irányában szigorúan konspirálva, informálisan, nevük elhallgatását kérve gyakorolták (kéréseiket a Jelentés összeállítása során akceptáltuk).

3.1.4. Mindebből részben az a tanulság vonható le, hogy az érdekvédelem és a közvetlen segítségnyújtás ebben az esetben - a közremüködő segítők szintjén - nem különült el élesen egymástól, ki-ki helyzetének függvényében élt hol az egyik, hol a másik eszközzel, szintén a helyzettől függően különböző típusú eszközökkel.

\subsection{SZERVEZETI SZINTUU TANULSÁGOK}

Az ügyben közremüködő szervezetek szintjén a következőket lehetett megállapítani:

3.2.1. A vagyongazdálkodási iroda ugyan egy ideig a Lakástörvény-beli és a vonatkozó helyi rendelet-beli elóírásoknak a betartásával végezte a feladatát, azonban később a megtett lépések jogszerüsége és ok-okozati összefüggése mégis csorbát szenvedett, elsősorban a szervezeten belüli információáramlás és a nyilvántartási rendszer problémái miatt. A vagyongazdálkodási iroda és K. M. közös képviselöje (az iroda volt munkatársa) közötti elszámolások, melyek alapvetően érintették K. M. ügyét (mind annak kezdetekor, mind annak folyamán) K. M. számára (is) áttekinthetetlenek, követhetetlenek voltak.

3.2.2. A helyi rendelet ugyan elöírja, hogy az önkormányzati bérlakások felmondása esetén a család- és gyermekjóléti központot erről tájékoztatni kell, azonban a megelőzést, prevenciót hatékonyabban szolgálná, ha úgy müködne a jelzőrendszer, hogy ez a tájékoztatás már a konkrét bérleti szerződés felmondása előtti (valóban utolsó) felszólításkor megtörténne. 65 év feletti lakó esetében az ún. utolsó Felszólítás kiküldésekor a család- és gyermekjóléti központ értesítése mellett a szociális szolgálat értesítése is megfelelöen szolgálná a megelőzést.

3.2.3. Ugyanez a Jelzőrendszer a család- és gyermekjóléti központ és társszervezete a szociális szolgálat között rendszerszerủen nem müködik, a szükséges információk oda-visszaáramlása nem megoldott, így egy-egy esetben az optimális munkamegosztás nem tud létrejönni. Az ügy egyik szakmai tanulsága, hogy a két társszervezet közötti információáramlást javítani kell, az ún. Intézményközi Esetmegbeszélő Team üléseket indokolt lenne rendszeressé tenni.

3.2.4. A konkrét ügy kapcsán az is megfogalmazható, hogy szükség lehet a Házi orvosi szolgálat és a helyi szociális szervezetek közötti Jelzőrendszer müködtetésére is, melynek során indokolt esetben, az érintett életvitelére hatást gyakorló állapotváltozás esetében a házi orvos jelzéssel élne akár a családsegítő, akár a házi gondozást szervező helyi szervezetek felé. 
3.2.5. Vizsgálatunk során ugyan rögzítettük a közösségi és egyéb elektronikus médiákban az üggyel kapcsolatban megjelent publikációkat, azonban a tényfeltáró vizsgálat nem terjedt ki e MÉDIA megjelenések tartalmi elemzésére. Azt azonban meg kell állapítanunk, hogy a konkrét ügy „harmadik szakaszában” a szereplők egy része igencsak aktívan használta a nagy nyilvánosság ezen eszközeit - a napi ügymenet eszközeként is. Ez számos segítő szakmai kérdést vet fel:

a. Felkészült, felkészíthetö-e az ügyfél arra, hogy egyszerre csak ügye a nagy nyilvánosság elé kerül?

b. Mennyiben segíti, vagy éppen torzítja, hátráltatja egy aktív, folyamatban lévő ügymenet előrehaladását, megoldását, hogy mindez a nagy nyilvánosság előtt zajlik?

c. Hogyan lehet ezeket a kérdéseket úgy megválaszolni - segítő szakmai szempontból -, hogy közben számolni kell azzal, hogy a nagy nyilvánosság fórumai a saját céljaik és logikájuk szerint müködnek, arra nincs befolyásunk?

d. Annyit a konkrét esetben megállapíthatunk, hogy súlyos vétségek is történtek a MÉDIA területén, olyan személyes adatok, fotók kerültek - az ügyfél hozzájárulása nélkül nyilvánosságra, melyek K. M. ügyfél-dossziéjának részei, ennyiben bizalmasak.

e. Azt is megállapíthatjuk, hogy meglehetősen szerencsétlen, olykor az abszurditást sem nélkülöző („,Szeretettel várjuk M nénit!”) üzengetés alakult ki a nyilvánosság fórumain K. M. „feje fölött".

f. Mindez befolyásolhatta a konkrét ügymenet folyamatát, a szereplők motivációit is.

\subsection{ESETKEZELÉS _ ESETVITEL TANULSÁGAI}

3.3.1. Feltehetően máshogy alakultak volna az események, ha a Háziorvosi szolgálattól 2018 őszén jelzés érkezett volna a helyi családsegítőhöz, vagy/és a házi gondozást szervező szolgálathoz.

3.3.2. Szintén esély lett volna a későbbi következmények elkerülésére, ha a vagyongazdálkodási irodára olyan szabály lett volna érvényben, hogy már a tényleges felmondás előtti utolsó figyelmeztetéskor tájékoztassák a csgyk-t - idős, beteg lakó esetében a szociális szolgálatot is - a felmondásra okot adó kéthavi lakbér-elmaradásról.

3.3.3. A rendelkezésünkre álló információk alapján azt kell rögzítenünk, hogy a vagyongazdálkodási iroda tájékoztatását követően a család- és gyermekjóléti központ munkatársa - egy sikertelen kapcsolatfelvételen túl - csupán hosszú hónapok múlva, a vagyongazdálkodási iroda ismételt megkeresésére vette fel először ténylegesen a kapcsolatot az érintett ügyféllel. Ennek lehetnek intézményen belüli kapacitásbeli, munkaszervezési okai, de lehet az is az oka, hogy két intézményi protokoll nincs harmonizálva (a vagyongazdálkodási iroda fölmondhatja a szerződést kettő havi hátralék esetében, ugyanakkor az adósságkezelési eljárás csak legalább hat havi tartozás esetén indul el), de lehetnek szemléletbeli okai is.

3.3.4. Mire a vagyongazdálkodási iroda ismételt megkeresésére a csgyk ismételten foglalkozni kezdett K. M. helyzetével, addigra már a lakásban - korábban nem tapasztalt - igencsak elhanyagolt állapotok alakultak ki.

a. A lakás (és az ügyfél) állapotát észlelve és rögzítve - megfelelő koordináció esetén - értesíteni lehetett volna a szociális szolgálatot, hogy vizsgálja meg részben a szociális takarítás, részben a házi gondozásba vétel szükségességét/lehetőségét, akár a későbbi tartós elhelyezés szakszerüen ütemezett előkészítését.

b. Ekkor már K. M. ugyan jogcím nélküliként lakott a lakásban, azonban a helyi rendeletnek köszönhetően, éppen ilyen esetekben mód lett volna még újra bérleti szerződést is kötni: 
„Akinek a bérleti szerződése a határozott idő elteltével dijhátralék fennállásával szünik meg, vagy dijhátralék miatt a bérbeadó a bérleti szerzödést felmondja, annak kérelme alapján a SZEB javaslatának figyelembevételével a polgármester engedélyezheti legfeljebb egy éves határozott idöre szóló ... bérleti szerzödés megkötését a jogcím nélkül használt lakásra."

(Forrás: Önkormányzat képviselö-testületének önkormányzati rendelete az Önkormányzat tulajdonában álló lakások és nem lakás célú helyiségek bérbeadásának feltételeiről.)

Tudomásunk szerint a díjhátralékokkal foglalkozó alapítvány ún. krízis támogatása is ilyen - vagy ennél sokkal nehezebb - helyzetekben nyújt, szükség esetén anyagi segítséget.

Ilyen kondíciók mellett szakmai szempontból nehezen érthetö, hogy az esetvitel miért nem elsősorban a lakás megtartására irányult.

3.3.5. Korábban már jeleztük, hogy a két közremüködő helyi szervezet, a család- és gyermekjóléti központ és a szociális szolgálat közötti információáramlás, szakmai kooperáció hiánya következtében miközben az egyik szervezet, lakossági bejelentés alapján K. M. házi gondozásba vételén kezdett el dolgozni, addig a másik szervezet már a lakás elhagyásának módját készítette elö.

3.3.6. Ugyanakkor az esetkezelés külső feltételrendszere szempontjából szintén nehezen értelmezhető a vagyongazdálkodási iroda munkatársainak azon lépése, hogy a július eleji bérlemény-ellenőrzésük során,

a. miután rögzítették, hogy a lakás rendezett, tiszta állapotban van, és

b. tudomásuk volt arról is, hogy - a helyi eljárásoknak megfelelően - önkéntes lakáselhagyás hiányában az önkormányzat jogi úton intézkedik (ahogy ennek elindítása ebben az esetben is az elöírásoknak megfelelően megtörtént), mégis

miért irányozták elő július végére a lakás önkéntes elhagyását, illetve miért nem várták be az egyébként szokásos módon - a jogi intézkedések (bírósági végrehajtás) soron következő lépéseit.

3.3.7. Az esetvitel iránya ugyan szakmai szempontból nehezen értelmezhető, a szervezetközi koordináció hiánya is felvethető, azonban kétségtelen, hogy a lakáselhagyást megelőző két hétben a csgyk munkatársa igen intenzív és kiterjedt tevékenységet végzett K. M. - lakásvesztést követő - lakhatásának a megoldása érdekében. Azonban sem ezt megelőzően, sem ekkor, sem a fejlemények tükrében nem állítható, hogy ez az intenzív tevékenység a kitűzött intézményi célon túl K. M. érdekeit szolgálta volna, az ügyfél megfelelően tájékoztatva lett volna, illetve e „megoldásokra” K. M. elégségesen fel lett volna készítve.

3.3.8. Az is megállapítható, hogy a munkatárs nem volt teljesen magára hagyva az esetvitel során, minden lényeges ponton vezetői felügyelet támogatta, illetve vezetői döntés határozta meg a konkrét továbblépés irányát. Nem tudunk arról, hogy a vezetői döntést team-megbeszélés, illetve team döntés előzte-e meg. Az azonban megállapítható, hogy az esetvitelről alkotott eltéró álláspontok esetén is a vezetői döntés a meghatározó.

3.3.9. Az is megállapítható, hogy a lakás konkrét elvesztésének fázisában, a kulcsátadást megelőző napokban a terepen, a legkülönbözőbb szervezetekben dolgozó, különböző státuszú közremüködő szakemberek ebben az esetben egymással közvetlen, vagy közvetett kapcsolatban tették a dolgukat, azonban az események, az esetvitel alapvető irányát nem ők, hanem a rajtuk kívülálló szereplők határozták meg. 
3.3.10. Ugyanakkor számos tényező megakadályozta, hogy az egymással kapcsolatba került szakemberek, szervezetek ebben a kritikus időszakban, ezekben a napokban összefogjanak és egy irányban dolgozzanak. Az esetvitelnek ez az ellentmondásos kezelése igencsak nehezen átláthatóvá, mondhatni áttekinthetetlenné tette a helyzetet az érintett, K. M. számára, s mindez persze meg is bosszulta magát a későbbiekben.

3.3.11. A helyi önkormányzat képviselője a médiában azt hangoztatta, hogy K. M.-et idősotthonban kívánják elhelyezni. Ugyanakkor nem történtek meg azok a lépések, amelyek szükségesek lettek volna ahhoz, hogy megállapíthassák, az idős hölgy valóban jogosult-e az idősotthoni elhelyezésre, illetve szüksége van-e arra. Az idősotthoni elhelyezést ugyanis a törvényi előírások szerint (lásd: 1993. évi III. törvény a szociális igazgatásról és szociális ellátásokról, 6768. §) meg kell előznie az előgondozásnak és ezen belül a gondozási szükségletvizsgálatnak, ami bizonyíthatja, hogy az idős személy önmaga ellátására nem vagy csak folyamatos segítséggel képes, és így jogosult az idősotthoni ellátásra. Amennyiben a gondozási szükségletvizsgálat alacsonyabb fokú szükségletet állapít meg, a házi segítségnyújtás jelenthet meg-oldást. K. M. esetében a szociális szolgálat csak előzetes felmérést végzett, de egyértelmüen a házi segítségnyújtásra látta jogosultnak az idős hölgyet. Semmi nem utalt arra, hogy ne lenne képes vagy csak folyamatos segítséggel lenne képes az önellátásra. Az pedig végképp érthetetlen, hogy ha a K. M.-et segíteni hivatott szociális szakemberek az idősotthoni elhelyezést látták szükségesnek, akkor azt - különleges sérülékenységére való tekintettel - miért nem várhatta meg a saját lakásában!

3.3.12. Megállapítható, hogy az esetvitel során nem lett kellően figyelembe véve az ügyfél sérülékenysége, idős kora. Az utólagos vizsgálat során nem volt megállapítható, hogy $\mathrm{K}$. M. a lakáskulcsok önkéntes átadásakor mennyiben tudta felmérni, hogy melyek maradásának a lehetőségei, illetve távozásának a következményei. Az előzményekből az állapítható meg, hogy ezt megelőzően a lakásban maradásának a lehetőségeiről a csgyk munkatársa nem tájékoztatta megfelelően. (A kulcsátadást megelőző napokban bekapcsolódó érdekvédők tájékoztatták erről.) Távozásának irányáról annyit tudhatott - az előző hetekben lebonyolított felvételi beszélgetések alapján -, hogy valamilyen, idősekkel foglalkozó hajléktalanszállóra, vagy idős otthonba kell költöznie. Az átmeneti szállót korábban nem látta.

3.3.13. A lakás elvesztése utáni első napokat követően K. M. ideiglenesen a diszpécserszolgálat által felkínált szállón jutott ellátáshoz, majd rövid időn belül hajléktalanok (idősek) otthonában jutott idősotthoni ellátáshoz. Az itt kapott ellátás megfelelt a tartós bentlakásos ellátás követelményeinek, mely - a lakásába történő visszaköltözés szándékát fenntartva - megfelelt K. M. számára. Kapcsolata a lakóhelye szerinti segítőkkel (akár a családsegítőből, akár a szociális szolgálatból) teljesen megszakadt, esetátadásra, vagy bármilyen információcserére az új és a korábbi segítők között - jelenlegi gondozója közlése szerint - nem került sor.

3.3.14. Végül, azt is meg kell állapítanunk, hogy megítélésünk szerint K. M. ügye ugyan kirívó, de sajnos nem egy egyedi, különleges eset. A segítő szakmában nap mint nap találkozhatunk ilyen és ehhez hasonló „történetekkel”. Az sem egyedülálló, hogy ilyen sokan és ilyen intenzíven együttmüködve, vagy éppen ,fejetlenül” - dolgoznak egy-egy ember, vagy család ügyén, melynek során a kitüzött intézményi célok felülírják a bajba került polgár jogos érdekeit.

K. M. ügye, éppen azért érdemelhet különös figyelmet, éppen azért szolgálhat különösen fontos, általános tanulságokat a segítő szakmában dolgozók számára, mert meglehetősen egyértelmúen rávilágít számos, intézményen belüli és kívüli, a segítő munka során elkövethető és elkövetett hibára, súlyos visszásságra. 
2019. szeptember közepén a tényfeltáró vizsgálatot lezártuk és a Jelentés-tervezetet észrevételezésre megküldtük az érintetteknek, illetve átadtuk és felolvastuk K. M.-nek, kérve észrevételeit és írásbeli hozzájárulását a publikáláshoz.

K. M. ügye ekkor még nem rendeződött, ő - kisebb pontosításokkal - szívesen hozzájárult a publikáláshoz. Ezzel szemben az ügyben érintett helyi önkormányzati intézmények vezetői közös levélben fordultak a vizsgálatot kezdeményezö szakmai szervezet vezetőjéhez, azzal, hogy a nyilvánosságra hozatalhoz semmiképpen nem járulnak hozzá. Az ő személyes közléseik így kihúzásra kerültek a Jelentésböl.

A szeptember végéig beérkezett részletes észrevételek alapján véglegesítettük a Jelentést és megküldtük a felkérő szakmai szervezet vezetőjének. A szakmai szervezeten belül a Jelentés, illetve a Jelentés szakmai nyilvánosság elé tárása komoly vitákat generált, a szakmai szervezet az adatvédelmet nem látta biztosítottnak sem az érintett személy, sem az ügyben szerepet játszó szervezetek és szakemberek esetében. A szervezeten belül több hónapon keresztül tartó vitában a vizsgálatban érintett intézményekhez - személyes, vagy munkajogi szálakon - kapcsolódó tisztségviselők is jelentős szerepet játszottak.

Végül a Jelentés publikálására és az eset nyilvános szakmai vitájára nem került sor.

2019. október 13-án önkormányzati választások voltak, melynek során némileg megváltozott az önkormányzat képviselőtestületének összetétele. Ez is közrejátszhatott abban, hogy végül, az ügyben érintett helyi önkormányzati intézmények ellenállása ellenére - kitartó tárgyalásokat követően - november legvégén aláírásra került egy lakáshasználati szerződés és december elején K. M. visszaköltözhetett önkormányzati bérleményébe, ahol a helyi gondozó szolgálat szolgáltatásait is igénybe veheti.

\section{Lezárás}

A Jelentés egy szakmai szervezet felkérésére készült. Az ad hoc munkacsoport elsődleges célja a felkérésnek megfelelően - a történtek sok szempontból történő megismerése és tényszerü leírása volt. Ezen túl azonban már a munka kezdetekor megfogalmazódott, hogy a munkamódszerek megválasztása és pontos definiálása is lényegi feladat. Amennyiben a szakma önmaga számára feladataként fogalmazza meg a szociális szolgáltatások müködési jellemzőinek vizsgálatát, a vitatott ügyek áttekintését, akkor annak elengedhetetlen feltétele a független szakmai tényfeltárás protokolljának kialakítása is. 
A Jelentésben foglalt tartalmi - szakmai tényeknek és tapasztalatoknak megvitatásáról, valamint a Jelentés módszertani alkalmazhatóságáról szólt volna az a szakmai fórum, melyet a tényfeltáró munkát elindító szakmai szervezet koordinált volna. Ez azonban nem jött létre. Valószínűleg az egyik akadály éppen a Jelentés rendhagyó tényfeltáró jellege volt. Nincs tapasztalat, kialakult rutin az ilyen jellegü esetfeltárások és leírások készítésében és hasznosításában. A bizonytalanságokat fokozta, hogy jelentősek az értelmezési eltérések a GDPR-ból adódó felelősségek megítélésében is.

A szakmai szervezet ezekben a kérdésekben bizonytalan volt, az egész folyamat alatt semmilyen módon nem állt ki az ügyfél érdeke mellett, illetve késői és erőtlen volt a megszólalása a szakszerü és etikus szakmai munka védelmében. Az elkészült Jelentés fokozottabb adatvédelmi módosítására nem tett javaslatot, illetve a munkacsoport tényfeltáró munkáján alapuló megállapításait tartalmazó fejezet (3. fejezet) nyilvánossá tételét és vitáját sem vállalta fel.

Mivel az eset és az esetfeltárással összefüggő szakmai bizonytalanság szakmai átgondolását és vitáját egyaránt fontosnak tartjuk, a Jelentést adatvédelmi szempontból a szervezetnek leadotthoz képest még átdolgoztuk, anonimizáltuk, az ahhoz csatolt mellékleteket kivettük, és ebben a formában most nyilvánosságra hozzuk. Tesszük ezt azért is, mert más országok ilyen jellegü rutinszerü gyakorlatát látva ${ }^{1}$ fontosnak és halaszthatatlannak tartjuk, hogy a hazai rendszer is képes legyen objektív és nyilvános szakmai tényfeltárásra, valamint a tapasztalatok mindennapi gyakorlatban történő hasznosítására.

\section{Melléklet}

\section{NÉHÁNY ALAPVETÉS AZ AD HOC TÉNYFELTÁRÓ MUNKACSOPORT ELJÁRÁSAIRÓL}

\section{1) INFORMÁCIÓKEZELÉS - ÁLTALÁNOS}

a) A vizsgálat ideje alatt és azt követően is a munkacsoport tagjait minden olyan személyes információkra vonatkozóan titoktartási kötelezettség terheli, melynek közléséhez az információt adó személy nem járult hozzá.

b) Nyilvános nyilatkozatot, bármilyen információt a vizsgálati Jelentés elkészültéig a munkacsoport tagjai semmilyen formában nem adnak.

c) A Jelentés elfogadását követően a munkacsoport tagjainak hozzájárulásával adható nyilvános nyilatkozat, megnyilvánulás.

d) Az etikai és adatvédelmi elöírásokon túl a munkacsoport tagjai figyelemmel vannak az érinett, az információt szolgáltató egyéni helyzetére, kalkulálható kockázataira

\section{2) SZEMÉLYES TALÁLKOZÁS:}

a) A munkacsoport tagjai törekednek arra, hogy minden, az ügyben közremüködő személlyel személyesen beszéljenek a közremüködés céljáról, módjáról, körülményeiröl (hely, idő), személyes értékeléséről.

b) A személyes beszélgetések időpont egyeztetés előzi meg (telefonon, emailben, levélben...), a megkereséskor, vagy a kontaktus létrejöttekor a Megbízólevél másolata a közremüködő részére átadható, illetve emailben elküldhető.

c) A közremüködőket a munkacsoport tagjai tájékoztatják a vizsgálat céljáról, módszeréről, eljárási rendjéröl.

\footnotetext{
${ }^{1}$ 1. például az angol gyermekvédelmi példákat a https://learning.nspcc.org.uk/case-reviews/ oldalon
} 
d) Hangfelvételt (vagy képfelvételt) a munkacsoport tagjai nem készítenek, kivéve felmerülő speciális igény esetén, de ekkor a felhatalmazásnak a felvételen szerepelnie kell, vagy írásos felhatalmazásra van szükség

e) Személyes találkozás során a kézi jegyzetek készülnek, illetve közvetlenül a kontaktust követően ki-ki leírja a beszélgetés tartalmát, körülményeit stb.

3) DOKUMENTUMOK:

a) Akár betekintés, akár megküldés esetén rögzítésre kerül a dokumentum pontos neve (hol, ki, milyen szervezet állította ki), pontos dátumozása, és a dokumentum tartalmának kivonatos lényege.

b) A vizsgálatot követően a megkapott (lehetőleg anonimizált) dokumentumokat a munkacsoport tagjai megsemmisítik, oly módon, hogy az illetéktelen kezébe bizonyosan ne kerülhessen.

c) Egyebekben a dokumentumokban, illetve a személyes találkozókon megismert információkar az említett általános szabályok érvényesek.

4) EGYEBEK

a) A munkacsoport tagjai szóban és írásban osztják meg egymás között az információkat, a Jelentés közös megírása érdekében.

2019. augusztus 12 .

Aczél Ágnes Darvas Ágnes Győri Péter Kozma Judit Tánczos Éva 